\title{
Construction Morphology Analysis of Compound Verbs in Igho Language
}

\author{
Jennifer Ujunwa Okoli * \\ (University of Nigeria, Nigeria) \\ Comfort Nwuka Ezebuilo ** \\ (University of Nigeria, Nigeria) \\ Sopuruchi Christian Aboh ${ }^{* * *}$ \\ (University of Nigeria, Nigeria)
}

\begin{abstract}
This research analyses compound verbs in Igbo, using construction morphology theory. It seeks to identify compound verbs, analyse them using schemata structures, ascertain the structures and behaviours of tones, and examine some inflected forms of compound verbs in Igbo language. The study adopts a descriptive method of data analysis to examine data collected through oral interviews, introspections (which are confirmed by two native speakers) and those obtained from journals and textbooks. The research discovers that some compound verbs do not obey the vowel harmony rule, and through the aid of the schema, it is observed that some transformational processes have occurred before a surface compound verb is formed. According to the findings, tones also play a distinctive role in Igbo compound verbs. The research recommends further research in this area, to account for other aspects of compound verbs in Igbo that the current study could not cover.
\end{abstract}

Keywords: construction morphology, verbs, compound verbs, Igbo

\section{Introduction}

Compounding is a morphological process used for deriving new words in a language. Plag (2002) asserted that the study of word formation can be defined as the study of ways in which new complex words are built on the basis of other words or morphemes. Compound verbs are a type of compounding which involves a sequence of two or more verbs formed as one word. Compound verbs and verb compounds have received critical

\footnotetext{
* Jennifer Ujunwa Okoli: Department of Linguistics, Igbo and Other Nigerian Languages, University of Nigeria, Nsukka, Nigeria. Email: okolijenny84@gmail.com.

** Comfort Nwuka Ezebuilo: Lecturer II, Igbo Syntax, University of Nigeria, Nsukka, Nigeria. Email: comfort.eze@unn.edu.ng.

*** Sopuruchi Christian Aboh: Corresponding author of this paper, Graduate Assistant, Sociolinguistics and Igbo Studies, University of Nigeria, Nsukka, Nigeria. Email: sopuruchi.aboh@unn.edu.ng.
} 
attention from Igbo linguists (Lord, 1975; Onuoha, 1990; Mbah, 2004; Oha, 2010; Mbah \& Mbah, 2012; Mbah, 2018; Onwukwe, 2018). What is lacking in these researches is an analysis of compound verbs in Igbo language using the theory of construction morphology. The researchers believe that using construction morphology as a framework can better solve the problems in the study of compound verbs in Igbo language.

Construction morphology theory was developed by Riehemann (2001) and Booij (2010a, $2010 \mathrm{~b}, 2013)$. The theory takes a word-based perspective of analysing complex words to the morpheme-based approach manifested in the theory of distributed morphology. It claims that these complex words can be represented or outlined in the lexicon of that language, which are abstractly represented in the mind of the native speaker. The theory assumes that a learner starts with learning individual words and when he is acquainted with them, starts coining new words from the abstract lexicon in his mind, which he has been able to store.

It has been argued that verb compounding is a syntactic phenomenon, but a morphological perspective to it becomes pertinent (cf. Mbah, 2018). The general aim of this research work is to examine compound verbs in Igbo language using the theory of construction morphology. The specific objectives of this study are to identify compound verbs in Igbo language, establish the schemata structures for compound verbs, ascertain how verbal compounds in Igbo language can be inflected and determine the tonal behaviours of Igbo verbal compounds. All tone bearing units ${ }^{\circledR}$ in the data will be tone marked.

\section{Compound verbs in Igbo language}

The classification of compound verbs according to a head feature parameter shows that some compound verbs can be right-hand headed, left-hand headed or an argument sharing verb compound. This classification is based on the argument linking stem ${ }^{2}$ which has to do with the verb that best describes the focus of an expression by a native speaker, thereby forming the syntactic head while the conjoining verb may be prefixed or affixed depending on the position of the main stem or head verb (Oha, 2008). A few of these classifications based on Oha (2008) will be examined using construction morphology theory.

\subsection{Left-hand-headed compound}

In this type of verb compounds, the syntactic head of a compound can occur as

\footnotetext{
(1) Tone bearing units are phonemes that carry tones. In Igbo, tone bearing units are vowels and syllabic nasals $[\mathrm{n} / \mathrm{m}]$. When tone is assigned to vowels and syllabic nasals, any trace of ambiguity is resolved.

(2) This is used to describe a construction where is a cause-result event. The agent and the verb represent the causing event while the result event is expressed with the other elements in the predicate. The term 'stem' comes from the fact that there is no one verb root in verb compounds.
} 


\section{Jennifer Ujunwa Okoli, Comfort Nwuka Ezebuilo \& Sopuruchi Christian Aboh}

verb-initial (Lord, 1975). According to Oha (2008), some of the verb compounds that have this kind of occurrence include causative verb compounds and verb compounds of occurrence.

\subsubsection{Causative verb compounds}

Causative verb compounds are compound verb types in which a morpheme, expressing causation and another verbal root, amalgamates to form a lexeme with a cause-result interpretation. Examples of such are:

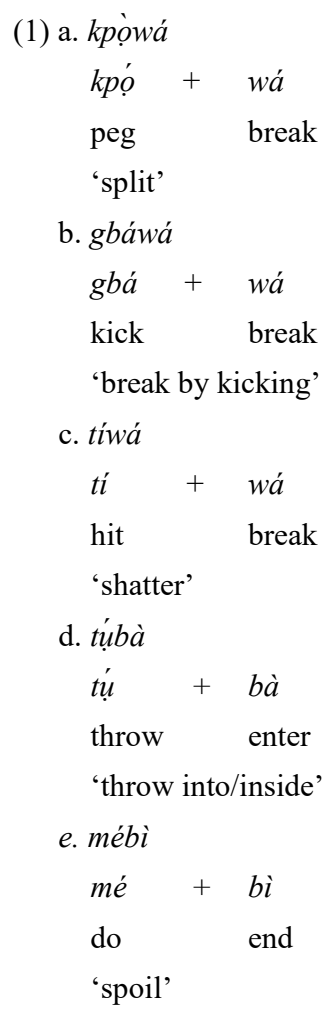

In the above example (1a-e), instances of causative compound verbs are given. The first component of the verbs $k p o, g b a, t i, t u$ and $m e$ are causatives because they stimulate a change of state of an object (Oha, 2008). Their prominent role in the verb compounds is the result of the left-hand position where they serve as the head of the verb compounds. Onwukwe (2018) adopts the feature percolation principle in accounting for verb compounds. He concurs that the head of a compound verb can be at the left-hand position. This is in contrast to Mbah's (2004) submission that a compound verb has no head based on his argument with transformational generative grammar. This is because he does not believe in the cause-action feature of Igbo verb compounds. 


\subsubsection{Verb compounds of occurrence}

Verb compounds of occurrence are a type of verb compounds that show the change of an entity without any force from an agent or instrument. They include:

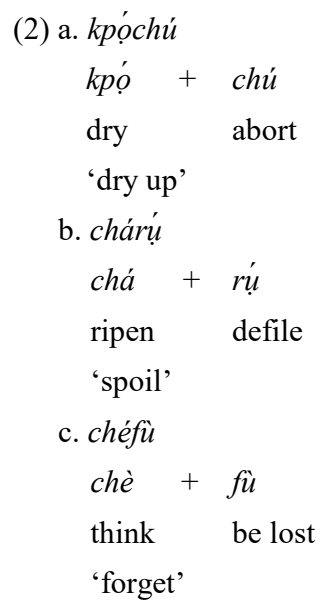

Example (2a-c) shows kpochu, charu and chefu as instances of verb compounds of occurrence in Igbo. As Uwalaka (1988) argues, verb compounds of occurrence capture scenarios where the state of the theme changes without any impact by any agent or instrument. In example (2a), a fish may dry up without any human being stimulating such transformation.

\subsection{Right-hand-headed compound}

Verb compounds that fall under this category have their syntactic head at the right-hand position. Some of them include:

\subsubsection{Same subject verb compounds}

These describe the type of compounds that have the same subject. Some examples include:

$$
\begin{aligned}
& \text { (3) a. tùgbú } \\
& \begin{array}{ll}
t u ̀+ & \text { gbú } \\
\text { peck } & \text { kill }
\end{array} \\
& \text { 'kill by pecking' } \\
& \text { b. tígbú } \\
& t i ́+g b u ́ \\
& \text { hit kill } \\
& \text { 'kill by beating' } \\
& \text { c. gbágbú } \\
& g b a ́+g b u ́ \\
& \text { shoot kill }
\end{aligned}
$$




\section{Jennifer Ujunwa Okoli, Comfort Nwuka Ezebuilo \& Sopuruchi Christian Aboh}

'kill by shooting'

In example (3a-c), the components of the verb compounds have the same subject. The second part of the verb compounds in each of the examples $g b u$ 'kill' carries the primary meaning. The first component carries the secondary meaning. In the examples above, the major meaning derived is that something has been killed. The first component provides how the killing was done: 'pecking' in (3a), 'beating' in (3b) and 'shooting' in (3c). In all, both components come together to convey information (cf. Ogwueleka, 1982; Oha, 2008).

\subsubsection{Motion verb compounds}

Motion compound verbs are verbs which indicate the movement of a person or an object. According to Uwalaka (1988), a motion verb compound is one in which the entity whose location is changed is responsible for the motion depicted in the event, as in:

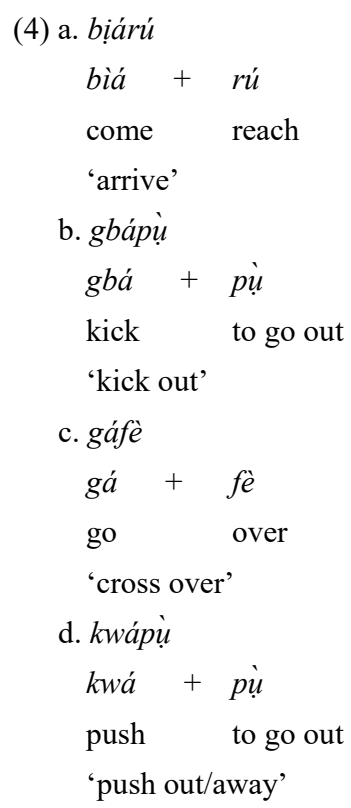

Motion simply means moving from one point to another. In (4a), the verb compound biaru 'arrive' denotes that an entity moved from point $\mathrm{X}$ to point $\mathrm{Y}$ either through road or by foot. In (4b) and (4d), gbapu 'kick out' and kwapu 'push away' respectively denote a quick movement from one point to another. (4c) denotes a careful movement from a point to another. In these compound verbs, the two components are motion verbs but when they are joined together, they are used to form an intense degree of motion.

The right-hand-headedness rule in the above verb compounds concurs with Lord's (1975) position that there are selectional restrictions in verb compounds. It will be syntactically unacceptable to change the position of the verb compounds above to " rùbịa, "pùgbá, " fègá and " pụkwá. 


\subsection{Argument sharing verb compounds}

Oha (2008:343) contended that in the argument sharing verb compounds, “...the two uniting verbs contribute their argument structures to the compound". Compounds that belong to this group include coordinate verb compound and verb compound of placement.

\subsubsection{Coordinate verb compound}

The coordinate verb compound is one of the compound verbs that is mostly but not solely derived from the verb - $r i$ 'eat' cluster, which joins with another transitive verb in the formation. Examples of such are:

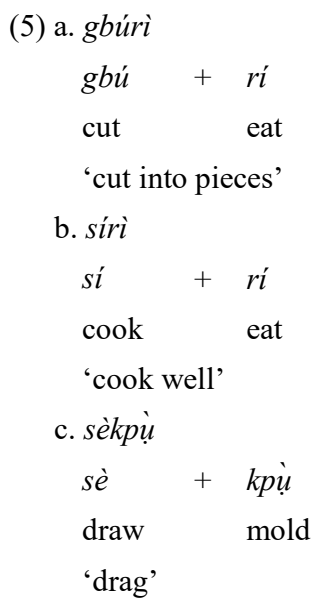

As is argued by Oha (2008), the components of the compound verbs are not ready to yield to each other. He further argues that both components can take the same arguments. In the above example, both the first and the second stems are transitive and share the same argument structure. Therefore, they satisfy to a great extent the argument structure with the same noun which must be found outside the compound (Lieber, 1983).

2.3.2 Verb compounds of placement

Verb compounds of placement predicate on the spatial location of their associated NP argument, sometimes brought about by the agent argument (Oha, 2008).

(6) a. dọnyé

$$
\begin{array}{ll}
\text { dọ } & \text { nyé } \\
\text { draw give } & \\
\text { 'carry into' } & \\
\text { b. gbùnyé } & \\
\text { gbú }+ \text { nyé } \\
\text { cut give } \\
\text { 'cut into' }
\end{array}
$$

In the examples above, the verb compounds capture an event where a change of state is 


\section{Jennifer Ujunwa Okoli, Comfort Nwuka Ezebuilo \& Sopuruchi Christian Aboh}

caused by an agent. In the above verb compounds of placement, there is a careful inversion of an elliptical argument into a place. In (6a), the act of carrying into is done carefully. For instance, glasses can be carried into a car carefully in order for it not to break. In (6b), gbunye can take the argument anu 'meat' as in gbunye anu n'ite 'cut the meat into the pot'. The two components of the verb compounds in the verb above have their event relations distributed over the argument (Oha, 2008).

\section{Construction schemata structure of verb compounds}

The construction morphology aids in establishing a schema for the analysis of complex words. An example of such complex words is compound verbs and this schema will be used in this section to disambiguate compound words and also show its simplest forms. The schema below shows the rule for complex word formation.

i. [[a] $\left.X_{k}[b] N_{j}\right] N_{j} \leftrightarrow\left[S E M, \text { with relation } R \text { to } \operatorname{SEM}_{k}\right]_{j}$

Drawing upon the rule above, a related schema is established as the rule used to analyse compound verbs in this analysis. The arrow represents the relationship between a particular form and a particular meaning. In other words, the arrow shows that the two sides are specified by co-indexation of the constituents (Akita, 2014). The variable "X" stands for major lexical categories, "a" and "b" stand for arbitrary sound sequence, while " $\mathrm{i}, \mathrm{j}$ and $\mathrm{k}$ stand for the lexical index on the phonological, syntactic and semantic" relation between the two parts of a compound (Booij, 2010a:4). The phonological mechanism "ip" accounts for a tone which may or may not restrict word formation, the syntactic mechanism " $\mathrm{j}$ " accounts for tense and suffix while the semantic mechanism "SEM" "k" account for the independent and the associative meaning of verb compounds. These indexes were devised to capture the peculiarities of our data. As such, the schema for analyzing Igbo verb compounds in this study is presented below:

ii. $\left[[\mathrm{a}] \mathrm{V} 1_{\mathrm{k}}[\mathrm{b}] \mathrm{V} 2_{\mathrm{i}}\right] \leftrightarrow[\mathrm{VV}] \mathrm{VC}_{\mathrm{j}}$

In (ii), where "V" is the verb, VC represents the verb compounds and "a" and "b" represent the first and second constituents respectively.

We shall be applying this schema to the various categories of compound verbs as follows:

(7) kpòwá 'split'

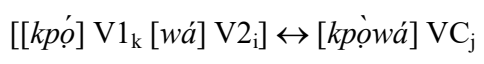

From the above example, the arbitrary symbol "k", which symbolises the phonological relationship between the two verbs, deals with vowel harmony and in kpowa, the vowels belong to the same +ATR category, which is called udamfe 'heavy vowels' in Igbo language. The symbol "i" represents their syntactic relationship, which shows that they are movement verbs. This class of verbs is left-hand headed because the morphemes express 


\section{Construction Morphology Analysis of Compound Verbs in Igbo Language}

causation as in kpọ, and the other verb root wá amalgamates to form a lexeme kpọwá with a cause-result interpretation. The second verbal compound wá is an intransitive verb while the first one is a transitive verb, and intransitive verbs do not take a direct object. For instance:

$$
\begin{array}{rll}
\text { (8) a. }{ }^{*} \text { Ada } & \text { kporo } & \text { Obi } \\
\text { Ada } & \text { called } & \text { Obi } \\
\text { b. }{ }^{*} \text { Ada } & \text { wara } & O b i \\
\text { Ada } & \text { split } & \text { Obi }
\end{array}
$$

The above example shows the impossibility of an intransitive verb to take on an object. The third symbol " $\mathrm{j}$ " also represents the semantic relationship which shows that the two verbs are related because the action of one verb necessitates the result of the other. This is in line with Lord's (1975) position that compound verbs in Igbo have action-result structure.

\section{(9) tíwá 'shatter'}

$$
\left[[t i] \mathrm{V} 1_{\mathrm{k}}[w a ́] \mathrm{V} 2_{\mathrm{i}}\right] \leftrightarrow[t i ́ w a ́] \mathrm{VC} \mathrm{j}_{\mathrm{j}}
$$

Igbo words often do obey the vowel harmony rule, but this pattern can be violated in some cases where there are borrowed or compound words. The $i$ in $t i$ and $a$ in wa are vowels emanating from two different vowel harmony groups, while $i$ belongs to the -ATR group and $a$ belongs to the +ATR group. The two verbs $t i$ and wá are verbs of movement. They possess meaning relationship in which $t i$ takes the action while wá takes the result of the action. It is also pertinent to note that elements of a compound do not express an action independent of each other. The above schemata in (8) and (9) are applicable to all the causative compound verbs.

$$
\begin{aligned}
& \text { (10) kpóchú 'dry up' } \\
& {\left[[k p o ̛ ́] V 1_{\mathrm{k}}[c h u ́] \mathrm{V} 2_{\mathrm{i}}\right] \leftrightarrow[k p o ́ c h u ́] \mathrm{VC}_{\mathrm{j}}}
\end{aligned}
$$

The schema above shows the realisation of the verb kpóchú by the concatenation of -kpó and -chú, and their relationship with each other. The vowels in the two verb roots are from different vowel harmony groups that $-o$ belongs to the +ATR group and $-u$ belongs to the -ATR group. The word kpọchú is a compound verb of occurrence, which means that the concatenation of these two verbs expresses how an event occurred. The two verbs have a meaning relationship because they denote the occurrence of something (showing that something had dried up).

$$
\text { (11) chárú 'spoil' }
$$

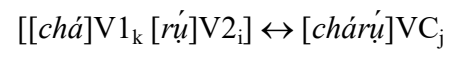

The vowels in the verb roots chá- and -rú are from the same +ATR vowel harmony group. Just like kpọchú, chárú is a verb of occurrence. The two verb roots also have semantic relationship because the two verbs merge to portray an occurrence. 
(12) gbágbú 'shoot to kill'

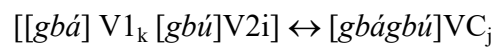

The phonetic relationships of these 'same subject verb compound' show their dissimilarity emanating from their divergence from separated vowel harmony groups ( \pm ATR group) respectively. There are some other same subject verb compounds where a similar group of vowels occur as that in tígbú and tùgbú. In these categories of compound verbs, the main expression is recognised through the verb gbu' 'to kill', while the other verbs or expressions, which might be $t i$, gbá or $t u$, are secondary to the main idea. For something to be killed, it requires another force, causing a hit on it.

(13) bịárú 'arrive'

$\left[[\right.$ bịá $\left.] \mathrm{V}_{\mathrm{k}}[r u \dot{u}] \mathrm{V} 2_{\mathrm{i}}\right] \leftrightarrow\left[\right.$ bị́árú] $\mathrm{VC}_{\mathrm{j}}$

The above example (13) is a motion compound verb comprised of two verb roots that

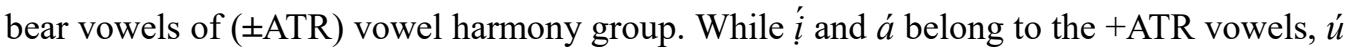
belongs to the -ATR vowels.

(14) gbúrì 'cut into pieces'

$\left[[g b u ́] \mathrm{V} 1_{\mathrm{k}}[r i] \mathrm{V} 2_{\mathrm{i}}\right] \leftrightarrow[$ gbúri $] \mathrm{VC}_{\mathrm{j}}$

The above example (14), which means 'to cut into pieces', is an example of a coordinate compound verb with a concatenation of two basic forms possessing a +ATR vowel harmony. Coordinate compound verbs always take a transitive verb, especially when derived through the concatenation of the verb -rí, which means 'eat', with another verb. Such verbs are always transitive, and this makes them violate the rule of the second verb supplying the argument structure of the compound because both verbs here require an internal argument. For instance:

(15) a. Ada gburu nku 'Ada broke fireword'

b. Ada riri nri 'Ada ate'

c. Ada gburiri osisi ahu 'Ada cut the tree into pieces'

In the above examples (15a-c), the verbs take on different objects independently. It takes the unification of these single verbs and the sharing of the same argument structure with the same noun for a simultaneous interpretation to be given. As such a complete compound verb can be deducted such as in (c).

(16) dọnyé 'carry into'

$$
\left[[\text { dò }] \mathrm{V} 1_{\mathrm{k}}[\text { nyé }] \mathrm{V} 2_{\mathrm{i}}\right] \leftrightarrow[\text { dọnyé }] \mathrm{VC}_{\mathrm{j}}
$$

dọnyé is derived from two verb roots which are dọ and nyé, which disobeys the vowel harmony rule of Igbo words by its combination of ( \pm ATR) vowels. This form negates any head/complement relationship, as none of the verbs function as the syntactic head. The above example (16) is called a placement verb because it gives information on the placement of an item. 


\section{Construction schemata for the inflected forms of compound verbs}

Inflection is the process of affixation or vowel changes that distinguish the forms of words in a grammatical category. It marks distinctions such as tense, person, number, gender, mood, voice and case. It is defined as a change in the form of a word to express its relationship with other words in the sentence or it can also be the process of varying the form of a word to differentiate elated meanings or uses. Its application does not change or alter the meaning of such words. In Igbo language, compound verbs can be inflected by attaching affixes to its basic form to mark tenses. It is agreed among Igbo linguists that verbs are the only grammatical categories in Igbo language that can undergo inflections (cf. Mbah, 2018). Therefore, inflections are used to mark tenses (present and past). The present tense is marked with a prefixed $-n a$ while the past tense is marked with an $-r \mathrm{~V}$ suffix in Igbo. The present tense and past tense are examined in this study because they have been adjudged as the tenses obtainable in Igbo language. The future tense is seen as a modal in Igbo (Mbah, 2018).

However, for the purpose of this study, we shall be focusing on establishing two different schemata that explain how the past and present tense in Igbo compound verbs are formed and few examples from section 2 will be used to explain the schema being established. In consonance with the general rule established in section 3, a schema for analysing the present and past form of compound verbs will be established as follows (AF stands for an affix):

Present Tense: $\left[[a] A F[b] V_{1}[c] V_{2}\right] \leftrightarrow\left[A F+V_{1}+V_{2}\right] \mathrm{VC}_{\text {PRS }}$

The above schema will be used to analyse the following examples as in:

(17) a. kpòwá 'split'

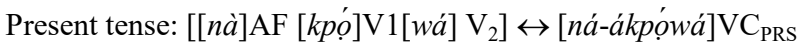

Nné $m$ ná-ákpówá àchàrà ànyị jì èsí nrí

Mother I PRS-split bamboo we hold cook food

'My mother is splitting firewood we will use to cook.'

b. kpóchú

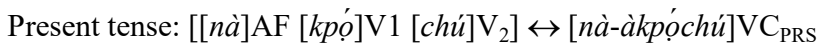

Akachukwu nà-àkpọchú azù

Akachukwu PRS-parboil fish

'Akachukwu is parboiling the fish.'

c. gáfè

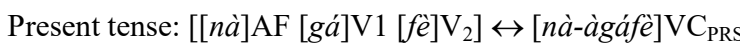

Kà ànyị nà-àgáfè n'ụlọ áhịà, ànyị hụrụ nnúkwú mmưọnwứ.

As we PRS-pass PREP-house market we see-PST big masquerade 
'As we were passing the market place, we saw a big masquerade.'

d. kwápù

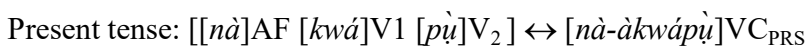

Nwáanyị ahù nà-àkwápụ ngwóngwó yá n'ezí

Woman DET PRS-bring-out property her PREP-outside

'That woman is bringing out her properties outside.'

e. gbùnyé

Present tense: $\left[[n a ̀] \mathrm{AF}[g b \grave{u}] \mathrm{V} 1[\right.$ nyé $\left.] \mathrm{V}_{2}\right] \leftrightarrow[$ à-ègbúnyé $] \mathrm{VC}_{\mathrm{PRS}}$

Nné nà-ègbúnyé igù n'úlọ éwú

Mother I PRS-cut-out frond PREP-house goat

'My mother is cutting palm fronds at the goats' pen.'

In the above example (17a-e), the schema shows how compound verbs can be inflected to form its present tense. The addition of the word present tense marker, $n \grave{a}$ - which means 'is', shows the present form of an action in Igbo language. Also, the prefixing of $n a-$ requires the addition of a participle, either $a$ or $e$, prefixed to the compound verb. The prefixed form follows the vowel harmony category of the first verb roots in the compound. For instance, in nà-àkpówá, $a$ is added to the compound because the vowel in the first component kpo also belongs to the +ATR. The processes of prefixing a participle and the use of the auxiliary verb $n a$ - to mark present tense are recurrent in examples (17a-e).

The past tense form of compound verbs can also be analysed in some examples below to show its validity.

Past Tense: $\left[[\mathrm{a}] \mathrm{V}_{1}[\mathrm{~b}] \mathrm{V}_{2}[\mathrm{c}] \mathrm{AF}\right] \leftrightarrow\left[\mathrm{V}_{1}+\mathrm{V}_{2}+\mathrm{AF}\right] \mathrm{VC}_{\mathrm{PST}}$

(18) a. kpòwá

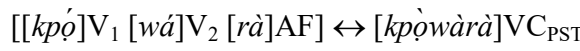

Anyị kpộwàrà àhụ úgbò ứkpáká áhù dárá n’àlà

We split-PST DET pod oil bean DET fall-PST PREP-land

'We split that locust bean pod that fell on the ground.'

b. kpóchú

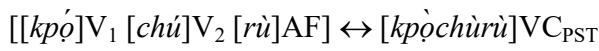

Azù áhù kpọchùrù ákpọchú

Fish DET parboil-PST bound verb complement

'That fish prematurely has dried up.'

c. gáfè

$\left[[g a ́] \mathrm{V}_{1}[f e ̀] \mathrm{V}_{2}[r e ̀] \mathrm{AF}\right] \leftrightarrow[$ gáfèrè $] \mathrm{VC}_{\mathrm{PST}}$

Ndí úwé ójii gáfèrè n'ụlọ ákwúkwó ányí táà

PL cloth black pass-PST PREP-house book we today

'Policemen passed through our school today.' 
Construction Morphology Analysis of Compound Verbs in Igbo Language

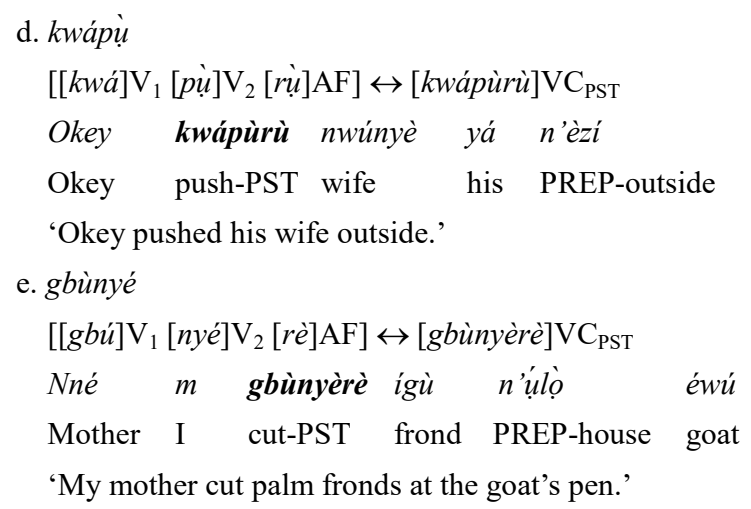

Drawing from the above examples, past tense is formed in compound verbs by the addition of the $r \mathrm{~V}$ stem. This is in line with Onuoha's (1990) morpho-phonemic approach to Igbo verb compounds which recognize the structure of "root + root + non-root". In the examples above, the two verb compounds are roots while the past tense marker is non-root.

In the formation of past tense in Igbo, the vowel to be attached to the past tense marker $r$ should be the same with the vowel in the $\mathrm{V}_{2}$ or a duplicate of the vowel of the $\mathrm{V}_{2}$. For instance, $e$, which is the vowel of the $\mathrm{V}_{2}$ in the compound verb gafe, will be suffixed to the past tense marker $r \mathrm{~V}$ in the $r \mathrm{~V}$ rule formation, which marks the formation of the past tense of gafe 'gafere'. This is applicable to the past tense formation of other compound verbs. In the construction morphology schema, the first verb compound component is labeled $\mathrm{V}_{1}$ whereas the second is labeled $\mathrm{V}_{2}$. The past tense marker is labeled AF which stands for an affix because the past tense in Igbo language is realised by suffixation. The resultant form after the merge of $\mathrm{V}_{1}$ and $\mathrm{V}_{2}$ as well as the affix is labelled [ $\mathrm{VC}_{\mathrm{PST}}$ ] which denotes verb compound in its past tense form.

\section{Tonal behaviours of compound verbs}

Sometimes, in Igbo language, the compounding of two words might bring about a tonal change different from the original tone, which the verbs bear in isolation. Some retain their inherited tone even when compounded. These tonal changes can also occur when inflected (either in their past or present form). There is a schema below that accounts for the compound verbs that do not change their inherited tone when compounded with another verb and those that change their tones respectively.

Verb-verb Compounds: $\left[\left[\mathrm{V}_{1}\right] \mathrm{x}\left[\mathrm{V}_{2}\right] \mathrm{y}\right] \leftrightarrow\left[\mathrm{V}_{1}+\mathrm{V}_{2}\right] \mathrm{xx} / \mathrm{xy} / \mathrm{yy}$

The above schema accounts for tonal behaviours of compound verbs that are not inflected. The arbitrary symbols " $x$ ", " $y$ " and " $z$ " are used to represent the high (H), low (L) and mid tone respectively. The symbol " $x$ " represents the high tone, " $y$ " represents the low tone while " $\mathrm{z}$ " represents the mid tone. The above schema is also employed in analysing 


\section{Jennifer Ujunwa Okoli, Comfort Nwuka Ezebuilo \& Sopuruchi Christian Aboh}

verb compounds whose tone changes, as a result of merging $V_{1}$ with $V_{2}$. "xx, $x y$, yy", show the associated tone of Igbo verb compounds in Igbo could be HH (xx), HL (xy) and LL (yy). These are notations devised in this study for easy indexing.

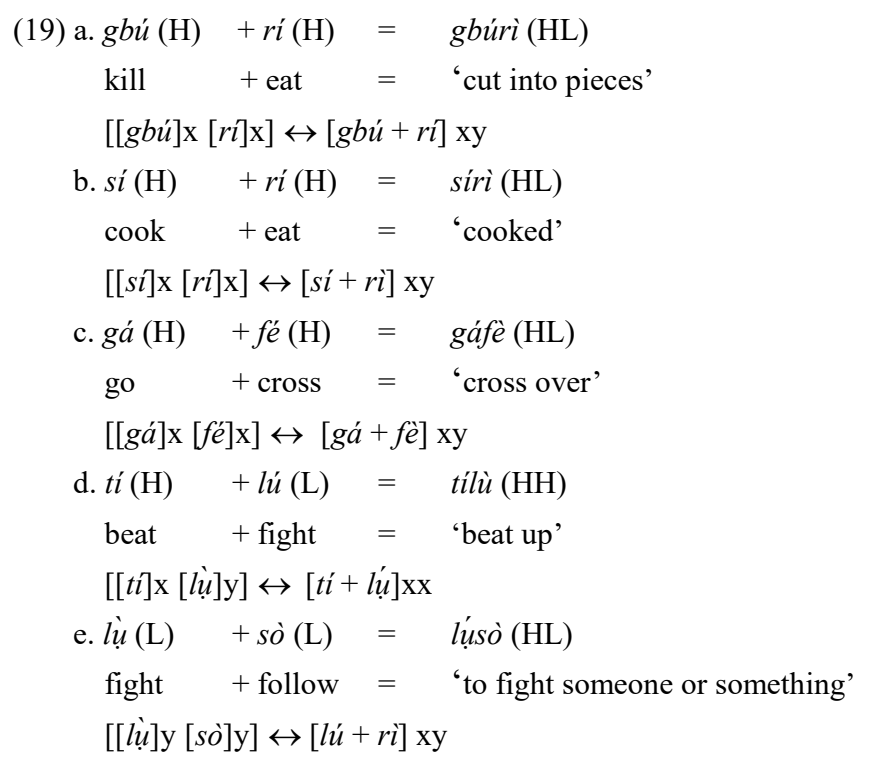

The above examples portray the changes that occur in the tonal level of some verbs in isolation and in combination with another. The left-hand side of the schema bears the inherent tone pattern of each verb while the right-hand side shows the changes that occur in their tone pattern as a result of the compounding process. Sometimes, tonal changes that occur in the same set of compounds bring about a change in meaning or turn to a command, question or a statement. Examples of compound verbs whose meanings change due to changes in tonal patterns are:

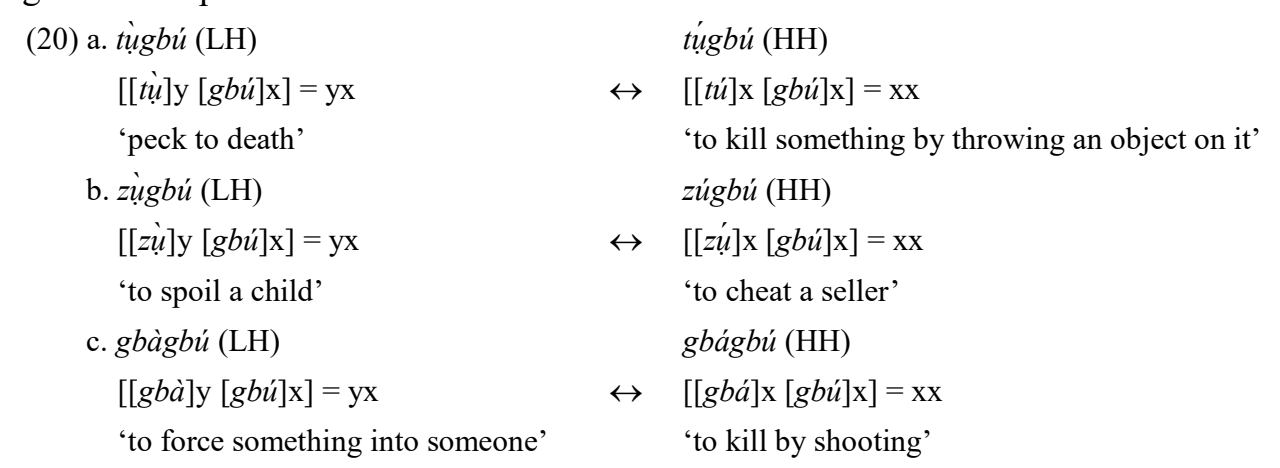

In the above examples, there is a change in meaning induced by the change in tone. In the above verb compounds, it can be seen that tone performs lexical function in Igbo language. In other words, the tone is semantic as it brings about change in meaning. The 
examples above concur to Mbah \& Mbah's (2012) position that the second verb maintains its tone pattern.

On the other hand, there are examples where the change in tone of verb compounds shows either a command or a statement. For instance:

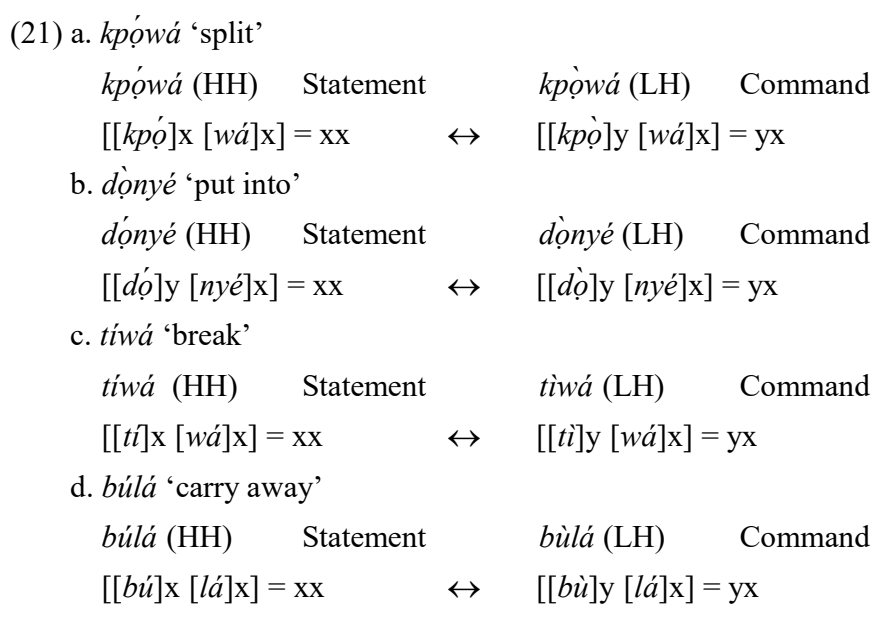

The examples at the left-hand side instantiate or exemplify where the compound verbs stand as a statement, while on the right-hand side, a low-high tone shows that the word is a command from the speaker to the addressee. In Igbo language, imperative constructions are often realised by low and high tones on disyllabic words. This tonal feature of imperatives in Igbo is observable in the above constructions. Example 21a, c and d concur to Mbah \& Mbah's (2012) phonological rule of Igbo verb compounds. Mbah \& Mbah (2012) posited that when there are identical tones, the tone of the first verb changes while the second is retained.

However, some verbs do not change their tones when compounded. Such verbs include:

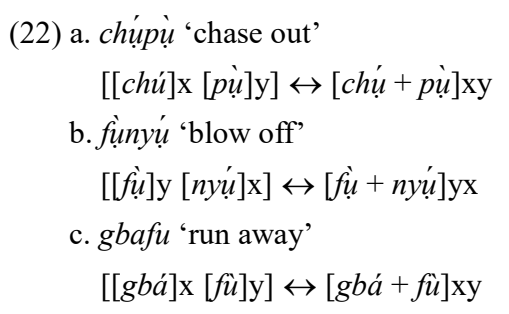

The compounding of these verbs above does not bring about tonal or meaning change. These are but a few in which this occurs. Sometimes, when Igbo words are inflected upon, they also bring about a change in their tonal behaviours. Considering compound verbs that are inflected to reflect them in either their present or past forms, tonal changes also occur, giving some of the compounds a new tonal pattern while some retain their tones. Igbo verb compounds, when inflected in their present form, do not have any specific tonal change, 
and the present tense marker which is ná-always bears a high tone. For instance,

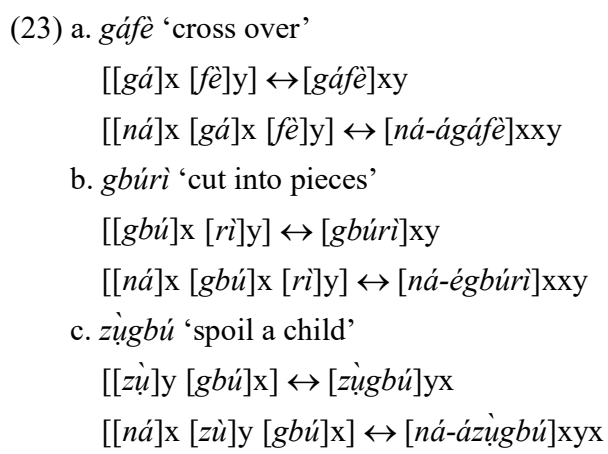

Examples (23a-c) capture instances of verb compounds that do not change their inherent tone when the auxiliary verb $n a$ - is attached to them. This tone retention does not change the meaning of the verb compounds rather it extends it. This is because inflectional morphemes are meaning-preserving and not meaning-changing.

Furthermore, there are some verb compounds that also retain their tonal pattern when a past tense marker $r \mathrm{~V}$ is attached to them, which is always conditioned by the tonal pattern of the $\mathrm{V}_{2}$ vowel in a compound verb. Some of these compounds are illustrated by the construction morphology schema as in:

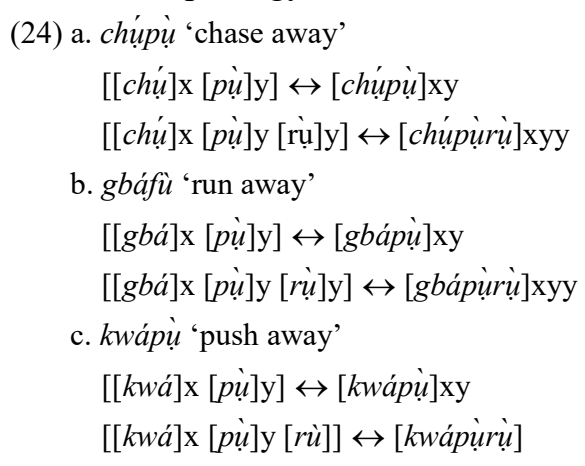

In the above examples (24a-c), the inherent tones of the Igbo compound verbs are retained. The addition of the past tense marker $r \mathrm{~V}$, which changes the compound verbs into a past event notwithstanding. Additional extension of the $-r \mathrm{~V}$ suffix in some cases, bring about tonal changes in the verb compounds. This can be exemplified with the following:

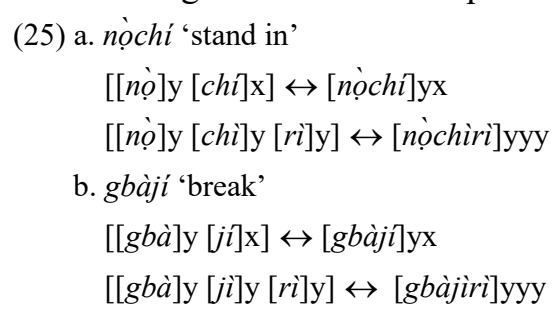




$$
\begin{aligned}
& \text { c. sèká 'tear' } \\
& \text { [[sè]y }[k a ́] \mathrm{x}] \leftrightarrow[\text { sèká] } \mathrm{yx} \\
& {[[s \grave{]}] \mathrm{y}[k a ̀] \mathrm{y}[r a ̀] \mathrm{y}] \leftrightarrow[\text { sèkàrà }] \mathrm{yyy}}
\end{aligned}
$$

Past tense markers of verb compounds always bear a low tone. From the examples (25a-c), the past tense marker with the $\mathrm{V}_{2}$ of the compound possesses a low tone to indicate an action that has already been done or completed. In arriving at the desired past tense meaning, the high tones in (25a-c) are changed to low tones. In associative constructions in Igbo, tones have the potentiality of being retained or changed. In the above examples, if the inherent tone of the second part of the compound verbs did not change, the construction will be meaningless.

\section{Conclusion}

This study explores compound verbs in Igbo using the theory of construction morphology. In line with the first research objective, the study discovers that the Igbo compound verbs can be classified into various sections according to the argument linking stem, which distinguishes the verb that best describes the focus of the compound. The compound verbs in this research are classified into three categories. Each of them is based on headedness. The first category contains the left-hand headed compound verbs, which deals with the cause-result type and those of which show the occurrence of an event. The second category portrays the right-hand head compound verbs that explain a movement process and compound verbs that refer to the same subject in a sentence. The last category (argument sharing verb compounds) shows compound verbs that share the same argument structure in a sentence.

The adoption of a construction morphology framework helps to identify the phonological, syntactic and semantic relationships that exist between two verbs that are compounded in Igbo language. In each of the categories of these compound verbs, it is observed that phonologically, some of the compounds do not obey the vowel harmony rule, which holds that in the formation of words in Igbo, the two sets of vowel category in Igbo language, the +ATR and the -ATR, should be observed and only vowel sounds from one set can co-occur. However, the rule is exceptional to compounds and borrowed words. As a result of this exception, some compound verbs violate this rule owing to the fact that these two words can stand in isolation where this rule is unavoidable and can still retain their meaning. Their syntactic relationship helps to show the type of compound verbs, which each of them belongs to, whether their concatenation portrays them as compound verb of motions, same subject compound verbs, causatives, and so on. It is also discovered that meaning relationships can also be determined when they refer to the same argument structure. The schema shows some of the transformational processes that have taken place 


\section{Jennifer Ujunwa Okoli, Comfort Nwuka Ezebuilo \& Sopuruchi Christian Aboh}

before a compound verb is formed. It is also discovered that the state of the compound verbs in isolation explains that the compounding processes do not affect the internal structure of the verbs.

From the inflectional aspect of compound verbs, compound verbs are classified as grammatically correct words. The study reveals that verbs are the only grammatical categories in Igbo language that can undergo inflections. Inflections are used to mark tenses (present and past). The present tense is marked with a prefixed -na while the past tense is marked with an $-r \mathrm{~V}$ suffix in Igbo.

The study concludes that the tone also plays a distinctive role in Igbo compound verbs. The construction morphology schema helps to illustrate changes that occur when two verbs are compounded. It is observed that some compound elements retain their sounds while others do not. Tonal changes bring about meaning changes, and imperatives can also be distinguished from a statement through tone. These tones also reflect in the inflected forms of verbal compounds, where the tone of a present tense marker - $n a$ copies the tone of the tone bearing unit after it, while the past tense marker $-r \mathrm{~V}$ also copies that of the tone bearing unit preceding it. The use of time to produce a correct form of a word in Igbo language shows their ability to exhibit tone pattern complexities. Finally, the research discovers that the Igbo compound verbs are highly productive. Their combination yields grammatically meaningful words, which broadens meaning and lexical components in the language.

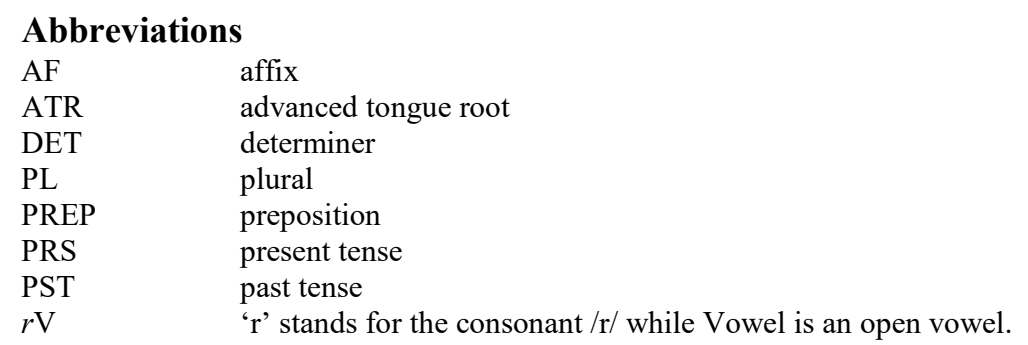

\section{References}

Akita, K. 2014. Construction Morphology [J]. English Linguistics, 31(1):275-283.

Booij, G. 2010a. Construction Morphology [J]. Language \& Linguistics Compass, 1(1):1-13.

Booij, G. 2010b. Construction Morphology [M]. Oxford: Oxford University Press.

Booij, G. 2013. Morphology in construction grammar [A]. In T. Hoffmann \& G. Trousdale (eds.). The Oxford Handbook of Construction Grammar [C]. Oxford: Oxford University Press, 255-273.

Lieber, R. 1983. Argument-linking and Compounds in English [J]. Linguistic Inquiry, 14(2):251-285.

Lord, C. 1975. Igbo Verb Compounds and the Lexicon [J]. Studies in African Linguistics, 6(1):23-48.

Mbah, B. M. \& E. E. Mbah. 2012. Phonological Features of Verb Compounds in Igbo [J]. Journal of West African Languages, 39 (2):99-114.

Mbah, B. M. 2004. Form a Paradigm: A joiner against nominal compounds in Igbo [J]. Nsukka Journal of 
Construction Morphology Analysis of Compound Verbs in Igbo Language

the Humanities, $15: 263-278$.

Mbah, B. M. 2018. Generalised Igbo Syntax [M]. Anambra: Amaka Dreams Limited.

Ogwueleka, O. S. 1982. Igbo Verbs and Expression of Semantic Relations [D]. M.A. Dissertation, Department of Linguistics, Igbo and Other Nigerian Languages, University of Nigeria, Nsukka.

Oha, A. B. 2008. Head Feature Parameter and the Igbo Verb Compounds [A]. In O. Ndimele, L. Udoh, L. \& O. Anyanwu (eds.). Critical Issues on the Study of Linguistics, Languages and Literature in Nigeria [C]. Nigeria: M. \& J. Orbit Communication, 331-346.

Oha, A. B. 2010. Verb Base Selection in Igbo Verb Compounding [J]. Journal of Linguistics Association of Nigeria, 13(2):359-372.

Onuoha, C. P. 1990. Syntax and Semantics of Verb Compounding in Igbo [D]. B.A. Project, Department of Linguistics, Igbo and Other Nigerian Languages, University of Nigeria, Nsukka.

Onwukwe, C. 2018. Percolation Principle Perspective of Verb-suffix Distinction in Igbo Verb Compounds [J]. Journal of Pan African Studies, 11(2):72-82.

Plag, I. 2002. Word Formation in English (Cambridge Textbooks in Linguistics) [M]. Cambridge: Cambridge University Press.

Riehemann, S. Z. 2001. A Constructional Approach to Idioms and Word Formation [D]. Ph.D. Dissertation, Stanford University.

Uwalaka, M. A. 1988. The Igbo Verb: A semantico syntactic analysis [M]. Wlen: Beilrage Zur Afrikanstic. 